Orbis Tertius, vol. XXIV, $\mathrm{n}^{\circ}$ 30, e127, noviembre 2019-abril 2020. ISSN 1851-7811

Universidad Nacional de La Plata

Facultad de Humanidades y Ciencias de la Educación

Centro de Estudios de Teoría y Crítica Literaria

\title{
Pensar en/desde/con/contra el archivo
}

\author{
Claudia Roman \\ Universidad de Buenos Aires, Argentina \\ balerdiroman@gmail.com
}

Trabajar archivos desata la serie preposicional. Y la desbarata porque el archivo es lugar, objeto, perspectiva de estudio, práctica, hipótesis; presupuesto del análisis y su conclusión. El archivo, los archivos son límite, deslinde taxativo y fuerza voraz que puede atraer cualquier elemento hacia así: contexto, referencias, alusiones, nuevos descubrimientos: todo a la vez. Y todo, mientras nos adentramos en él, con él, avanzando con la sensación algo insensata de intimidad amenazante con esa parva de materiales que creemos conocer de largas horas pero que, sabemos, está dispuesto a darnos una prueba en contrario en cualquier momento -después de todo, esa potencia y esa ambivalencia del archivo son parte fundamental de su seducción-.

Los seis trabajos reunidos en este dossier se encontraron primero en la conversación cotidiana entre sus autores y autoras, en el contexto del Archivo Histórico de Revistas Argentinas (https://www.ahira.com.ar). Como no podía ser de otra manera, cada artículo lleva, por eso, marcas de las preocupaciones individuales de las investigaciones en que se inscriben y también ciertos rasgos, un aire de familia, en el modo en que plantean sus preguntas. Los seis textos se ordenan apegados a la sucesión cronológica de las publicaciones de que se ocupan, en la certeza de que la historia (social, cultural, política, de las ideas y de las publicaciones) organiza y sostiene reenvíos y redes de circulación formales y discursivas que las hacen inteligibles, y que permiten comprender el alcance y el sentido de cada revista. Esa sucesión es también fundamental para vislumbrar el campo de las revistas como trama de citas, alusiones, debates y gestos refutativos.

Dado ese corte, la lectura -en cualquier orden- abre paso también a otros diálogos. El trabajo de Sylvia Saítta sobre Martin Fierro y el martinfierrismo opera como apertura metodológica que marca un tono del dossier en su conjunto, a partir de una metáfora fuertemente operativa, que reconfigura el problema de las revistas como objeto de estudio. La hipótesis central de su trabajo, apoyada en un estudio de caso, propone que ciertas revistas configuran un "campo gravitacional" que organiza tanto relaciones de diversa jerarquía con sus contemporáneas como en la larga duración, y que suscita y alberga, además, vínculos de esa revista con otros fenómenos culturales, sumamente heterogéneos entre sí (formaciones, polémicas, textos literarios). Varias de las restantes intervenciones retoman algunos de estos puntos. La lejanía en el tiempo entre la salida de La Quincena, de Rumbo, de Vigencia y de magazin literario (estudiadas, respectivamente, por Soledad Quereilhac, Magalí Devés, Martín Servelli y Diego Cousido) no es obstáculo para que lxs tres investigadores se pregunten por las revistas como condición de posibilidad de procesos de renovación estética fuertemente imbricados en sus condiciones políticas y culturales de emergencia. En el caso del análisis de Quereilhac, el registro minucioso y atento de la clásica revista "mosaico" finisecular permite elucidar, en la emergencia que habilita sus páginas, usos de la imaginación científica que proponen lazos inesperados entre la fantasía científica y el modernismo. Devés se detiene sobre un corpus muy distinto, los tres números de Rumbo -una publicación del campo intelectual de izquierdas, que marca un momento específico de su sociabilidad política e intelectual de entreguerras-. Posada en la sincronía y en esa intervención casi furtiva, la autora comparte la curiosidad sobre la capacidad de una revista para articular palabras e imágenes un imaginario que la excede ampliamente, con su propio sistema de rechazos, atracciones e influencias. Casi como una réplica inopinada, la perspectiva de Servelli sobre las relaciones que se tensan, medio siglo después, entre Vigencia, editorial Universidad de Belgrano y algunos de los proyectos literarios entonces emergentes y ahora canónicos -basta 
mencionar los nombres de César Aira, Fogwill y Ricardo Piglia- ilumina y es iluminado recíprocamente por el examen de Rumbo. En la cuidadosa reconstrucción que ejercita, la investigación de Servelli permite advertir algunos modos en que el espesor cultural de una época puede leerse también en revistas comerciales y masivas (incluso en aquellas adscriptas unívocamente, al parecer, a una perspectiva reaccionaria). El problema de la traslación de la "franquicia" francesa del Magazine Littéraire a la versión porteña también estimula, a su vez, en el planteo de Cousido, la pregunta por la articulación ideológica y cultural de una trama compleja, sus horizontes de posibilidad y sus límites.

En la zona más alejada al campo de atracción de las revistas, en el borde indeciso donde la serialización diseña un formato particular - el fascículo- para modelar un relato de la historia literaria nacional, se ubica el estudio de Manuela Barral sobre la primera versión de Capitulo. La tensión en el nombre elegido, que exhibe la dislocación entre el soporte fascículo y la referencia directa a la forma libro se revela productiva en múltiples sentidos: entre la biografía y la biblioteca, la periodicidad mensual de la publicación invita a la autora a preguntarse por la organicidad de esa historia literaria, y por las formas en que puede construirse una narrativa colectiva, como la que propone este proyecto, desde la variabilidad que supone esa frecuencia.

En los últimos veinte a treinta años han surgido valiosas herramientas teóricas para pensar el archivo y los archivos, hemos visto transformarse su materialidad mediante las posibilidades que ofrecen las plataformas virtuales y reconsiderar sus límites y alcances a través del llamado "giro digital" de las humanidades. ${ }^{1}$ Los seis trabajos que se leen a continuación buscan sumarse a esa ya larga conversación, en la convicción de que, con y contra todos esos desarrollos, la experiencia y la escritura del archivo siguen siendo, afortunadamente, resistentes y posible, gozosamente, inagotables.

\section{Notas}

1 Entre las múltiples obras de referencia teóricas e historiográficas dedicadas al estudio de las revistas, de su campo específico y del archivo como perspectiva de investigación, resulta imprescindible destacar el volumen colectivo dirigido por Dominique Kalifa, Philippe Régnier, and Marie-Ève Thérenty. La civilisation du journal: histoire culturelle et littéraire de la presse française au XIXe siècle (Nouveau monde éd, DL 2011), que, más allá de interesarse por un objeto notablemente más amplio, ha funcionado a la vez como una suerte de manual práctico, como marco epistemológico, como modelo de descripción/clasificación y como fuente de nuevas preguntas dirigidas a corpus muy diferentes del que aborda.

Además de los numerosos estudios de caso sobre revistas argentinas de todo tipo (literarias, científicas, culturales, masivas, ilustradas, virtuales...) producidas en el mismo período, son de mención ineludible, por supuesto, las historias panorámicas de las revistas, citadas en la bibliografía de los trabajos; los encuentros entre especialistas -como el Coloquio sobre Publicaciones Periódicas Argentinas, dirigido por Verónica Delgado y Geraldine Rogers, que viene teniendo lugar en forma sostenida y regular desde 2013 en la Facultad de Humanidades y Ciencias de la Educación de la Universidad Nacional de La Plata, y los imprescindibles volúmenes que recogen sus resultados-; y la puesta en disposición de trabajos críticos y de índices razonados en los diferentes repositorios digitales públicos y privados en actividad conforman un universo cuya sucinta enunciación es prueba suficiente de su productividad.

Por último, y por muchos y diferentes motivos, La vida en el archivo. Goces, tedios y desvíos en el oficio de la historia (Buenos Aires, Siglo XXI, 2017), de Lila Caimari, y el reciente Los archivos_papelespara la nación (Villa María, Eduvim, 2019) de Juan José Mendoza, expresan e inspiran algunas de las ideas y perplejidades borroneadas en esta presentación 